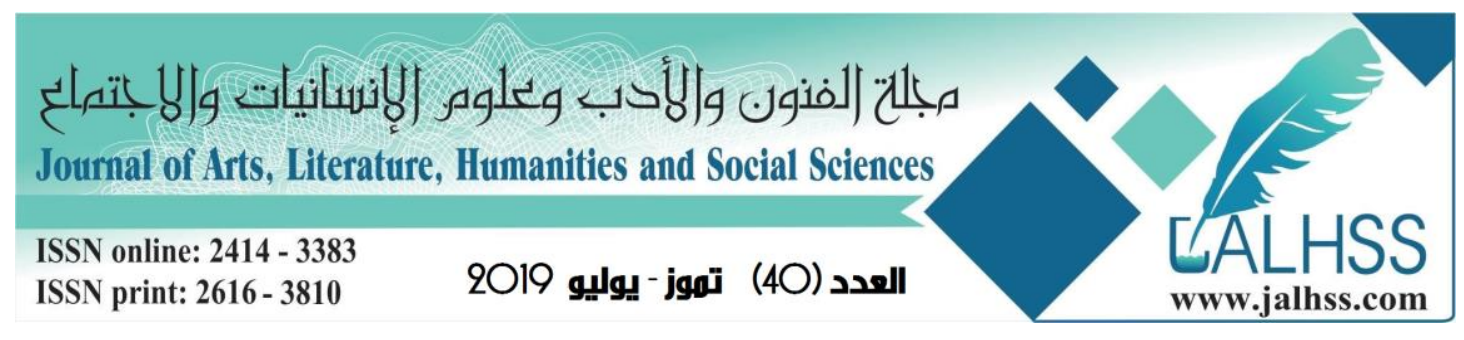

\title{
Agricultural Costs Accounting Role to Avoid Money Insolvency in Balak Agricultural Area
}

\author{
Ramyar Rzgar Ahmed \\ Dean, College of Business Administration and Economics, \\ Lebanese French University, \\ Erbil, Kurdistan, Iraq \\ Mobile: +9647504325252 \\ Email:ramear.walzy12@gmail.com
}

\begin{abstract}
The research is about the emergence and development of accounting and the demarcation of scientific foundations for accounting. The lack of application of the system in agricultural costs is analyzed in this study. Accounting agricultural costs in agricultural projects deals with the shortage of supply. Accurate data and information helps to make administrative decisions. The possibility of determining the actual and real cost of agricultural production helps to solve the insolvency of some farmers in agricultural projects in the Kurdistan Region. The study aims to identify the extent to which the agricultural cost accounting system can be applied in agricultural projects in the Kurdistan region and its role in avoiding financial insolvency. To analyze the researcher applied the scientific approach and studied the agricultural scenario in the Balk region. The objective of the study is to find out whether the application of agricultural cost accounting system helps to avoid agricultural insolvency. To obtain the objective the researcher collected data from 250 formers in the Balk region. The researcher witnessed that most of the farmers are funded by the Agricultural agencies. It is not necessary to apply an accounting system for agricultural costs and there is no assurance that Finance or loans are fully spent on the costs of agricultural activity. The study recommends the establishment of cost accounting departments in the agricultural projects and the application of the accounting system of agricultural costs in the agricultural projects in the Kurdistan Region
\end{abstract}




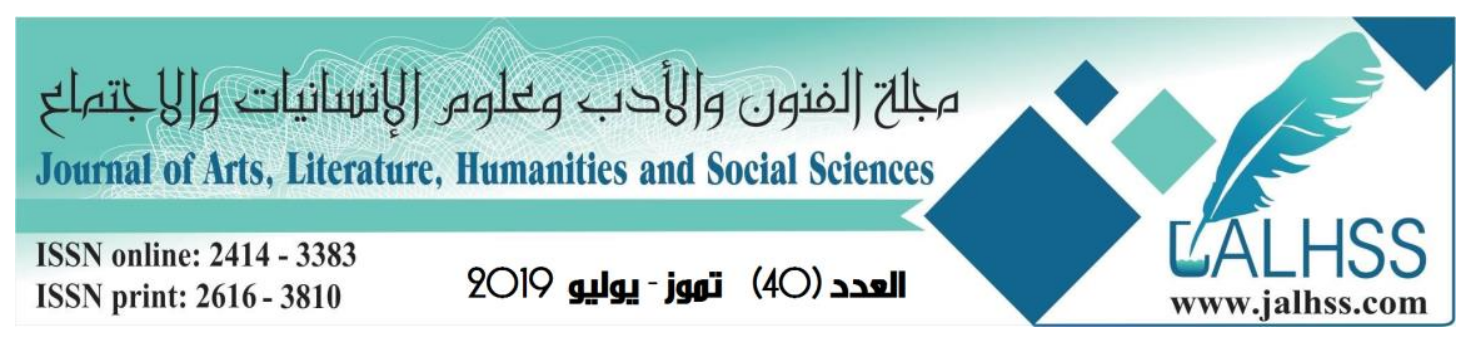

\section{Introduction:}

It is crystal clear that the developed countries today are raising the slogan for cost accounting system in the Agricultural projects to develop the lives of farmers. The emergence of modern technology has witnessed the development of accounting system in the agriculture even in the small countries around the world. Accountability for costs has become particularly important in providing information to the farmers. And the reports for decision-making, cost limitation and avoidance of financial risks are also provided to the farming projects by cost accounting system. The study focuses on the subject in detail and the accuracy in adopting the accounting system to rectify the problems related to the agricultural projects.

\section{Research problem:}

The problem of research is that there is a deficiency of application in the accounting system for the agricultural costs in agricultural projects. The researcher chose the projects in the Balak agricultural region as a model, in the extent to which agricultural cost accounting can be used as a mean to avoid the financial insolvency in agricultural projects. The case of Balak agricultural projects can be formulated as,

1. To what extent the cost accounting system in this project can be utilized and whether cost accounting system can avoid financial insolvency of farmers?

2. How far does the increased costs contribute to the agricultural farmers and the agriculture insolvency problems in general?

\section{Research objective:}

1. To propose methodological methods and scientific frameworks for the application of the Agricultural Cost Accounting System in agricultural projects such as the case of Balak agricultural projects.

\section{Study hypotheses:}

In order to prove the stratified aspects of this study, the researcher's opinion is that it is possible to test the following hypotheses:

1. The application of the agricultural cost accounting system that helps to avoid agricultural insolvency.

2. There is a statistically significant relationship between funding and means to avoid financial insolvency.

3. The application of accounting costs estimation leads to achieve the objectives of agricultural activity.

\section{Agricultural Cost Accounting}

Agricultural cost accounting is to adapt to the foundations and principles and procedures for different accounting systems and applied in units in accounting exercise activities or agricultural activities. 


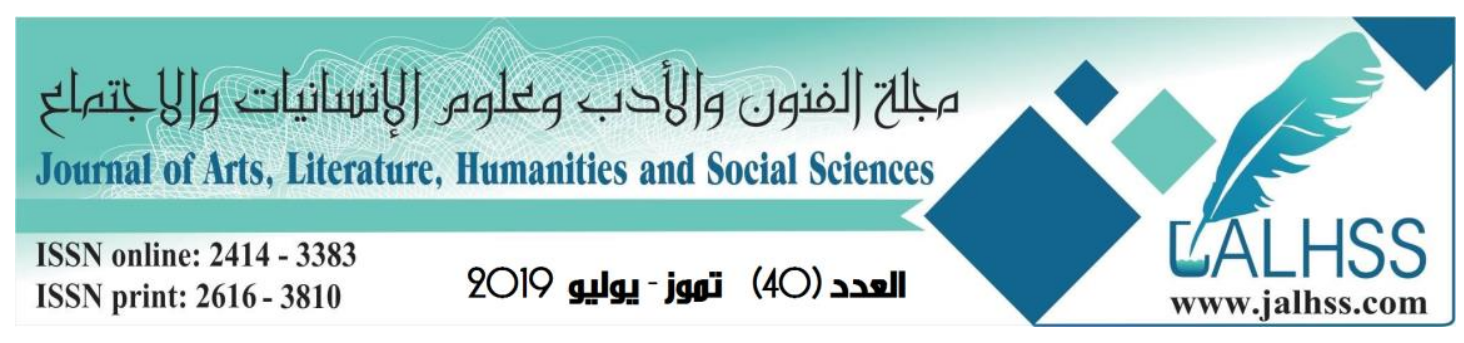

\section{Objectives of the system of costs in agricultural establishments:}

The objectives of the cost system in agricultural establishments include two sets of objectives

First: The general objectives of any Cost system in any facility,

Second: Installations related to agricultural, or in other words it can be said that the system cost targets in agricultural facilities are the overall objectives of the system costs of the characteristics of agricultural activity. It can be determined purposes for which it works costing system to achieve the same as follows:

First: Measure the cost of production: This objective is pursued by a rigorous system of cost accounting. It varies Production in agricultural establishments and varies according to the types of activity. For example, cultivation of certain crops and petting the domestic animals. The activity involves the raising of sheep, cows or hens for the purpose of producing milk or poultry products or the production of eggs for the purpose of fattening or for sale.

Second: Control elements of cost accounting in Agricultural: The design of the accounting system COST should include the control over the cost elements of factors. The development of an accurate system for control of the goods production at all stages, whether at the time of purchase, on receipt, storage, exchange, inventory and control over the cost of labor of all types. To make it clear it can be defined as the human, mechanical or animal related costs and the control of indirect costs (Schuyt and Brander 2004; Roseta-Palma 2003).

Third: Assistance in decision-making and policy-making: The cost system helps to manage the entity in its decision-making and policy-making task. With a large amount of quantitative and financial data the information that are assigned to it in its mission in the areas of production, marketing, finance and investment can be analyzed to make an opt decisions (Prabhu and Madanmohan 2014; Rabiyathul and Ramyar 2018;).

\section{The nature of agricultural activity and its components}

Agricultural activity consists in the broad meaning of the operations as group productivity and biological, industrial and manufacturing which target one or some of the following areas:

1- Cultivation activity: Seed and seed germination for the production of crops such as grain, cotton, various vegetables, medicinal plants, as well as production of fruits such as citrus, mangoes and others.

2- Animal Production Activity: A multi-branch activity involving livestock breeding, fertilization, milk production or propagation as well as obtaining wool from sheep. Even the interest of farmers in earning money in poultry, honey bees, horses, worms, etc. 


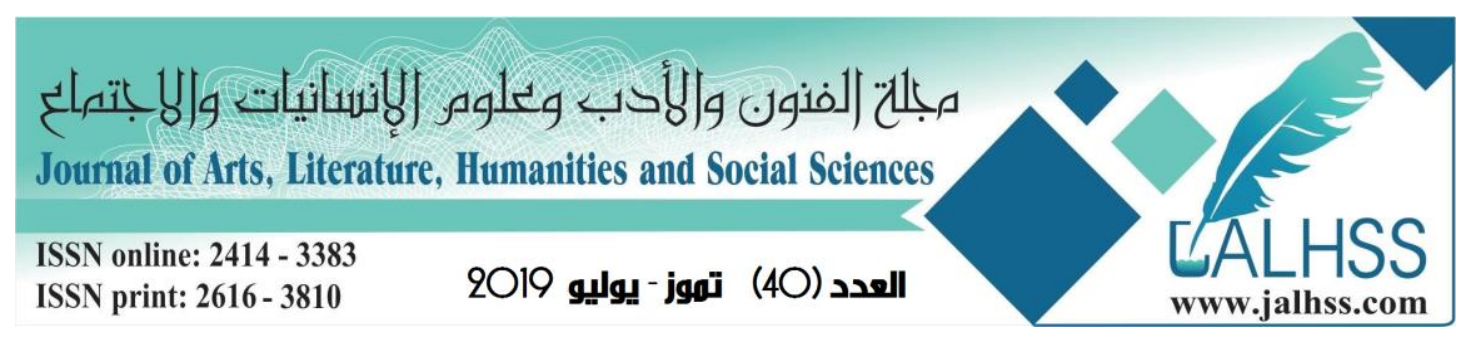

3- Land Reclamation Activity: It includes land clearing and land defrayal projects. To make the barren lands suitable for agriculture, which includes develop the areas of irrigation, drainage and dams. The desert land is also cultivated under this and is usually specialized and specific facilities in this type of activity is away from the other agricultural activities. The activity of agricultural processing and marketing of crops, includes the branches of small rural industries such as dairy products, oils and aromatherapy, aromatic oils, and in the area of marketing, the activity includes the filling and packaging facilities of agricultural crops for exports or local marketing and the consequent transportation from agricultural production areas to consumption sites and wholesale markets. This activity can extend to the storage operations at specialized storage units with refrigerators for freezing and preserving the perishable agricultural products like fruits and vegetables (Richard and Paul 2003; Murices Moon 1999; Nambirajan and Prabhu 2011).

\section{Agricultural activity characteristics and implications of accounting:}

The agricultural sector is characterized by multiple advantages, each with some of its implications. The accounting aspect, especially in the selection of the appropriate accounting system, even though they differ in depth of the usages can be utilized if used properly. The researcher addresses the characteristics and analysis of the study and determine through its accounting implications.

First: Linkage of farm work to rural livelihoods:

As agriculture is a way of life to earn the daily bread, there is a close connection between work farm and farm in the countryside, where the farm dwelling and farm are one productive unit. It is difficult to separate them, but some agricultural processes are also done as the home products. The farmers' family members also contribute to the agricultural work and thus serve as a source of labor humanitarian assistance. In the opinion of the researcher, there are some accounting problems, especially those relating to the inventory, analysis and loading of labor and additional costs. Therefore, it is necessary to address the phenomenon of the need to calculate the wages of ideals (ie, light). The prevailing wages for such works in the area where the farm is located (Hoehn and Alan 1989; Hassan 2007; Rabiyathul and Ramyar 2019).

Second - Second Season of Agricultural Production:

Agricultural production is associated with natural conditions which is known as the seasons of the agricultural production. This phenomenon often leads to seasonal production at time periods of consumption and is the seasonal agricultural income. This is due to the fact that the modern trend provides the facility to cultivate some crops in different seasons using green houses and glass houses, etc., which is the 


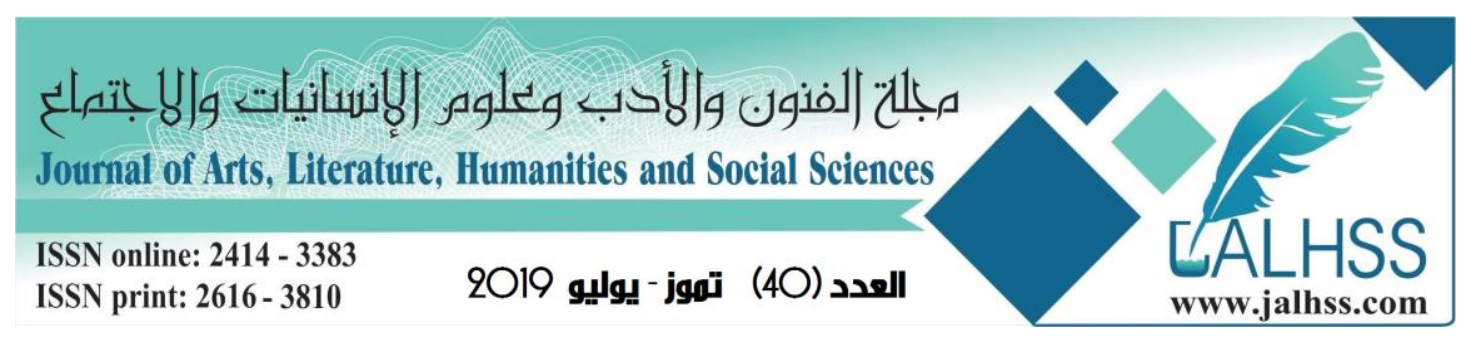

result of the need for large investments, which leads to increased costs and thus increase the cost of production unit.

Third: Multiple production units with small size:

Other characteristics include the large number of productive units with the same size, time, and it follows that the farmer cannot influence the market because only a small amount of the product adds to the huge quantities of the particular production available in the market. This will end up with farmers accepting the prices without being able to influence on it.

Fourth: Dealing with nature:

Agricultural activity is characterized by dealing with nature and subject to its provisions. The main production here is concentrated in soils and weather conditions such as heat, cold and rain as well as elements of human labor and goods. It follows this characteristic. It is difficult to estimate the exact quantities of production expected to be used in budgeting. Estimation is especially a long-term process.

Fifth: The high percentage of fixed capital in agriculture

Capital in agricultural production is generally the value of agricultural land and fixed assets in addition to the value of fixed establishment, in addition to value other capital assets such as agricultural machinery and capital assets traded necessary for spending on agricultural services and comparing the components of the invested capital Agricultural production. The ratio of fixed capital in the first to the second is higher which is not always the case and reflects the high proportion of fixed capital in agriculture.

Sixth: The multiplicity of agricultural products:

Most of the production units are characterized by the production of several products at the same time using the same Agricultural operations. Livestock produces meat, wool, leather and dairy products, and wheat produces cereals oriented products, and cotton produces seeds and cotton hair, and poultry produce meat and eggs. It should be noted here that these multiple products may be close to value or targeted in itself, the process of production and at the same level of relative importance in this case. These products are called common products. These may be basic products with different values. The main products are of great value and are called basic products. Low value products are called casual, secondary or sub-products. It is very important note that multiple products benefit from a single expense. These costs should be distributed commonly to these products in a rigorous and fair manner (Grady 2005; Abdullah and Mohd 2015).

Seventh: Comparability of agricultural products to damage:

Most of the agricultural products are characterized by their perishable speed, especially in some time limits and in some areas. This characteristic reflects its significant impact and is a burden on where it is necessary to:

1. Store with appropriate specifications.

2. Transport media of a certain nature. 


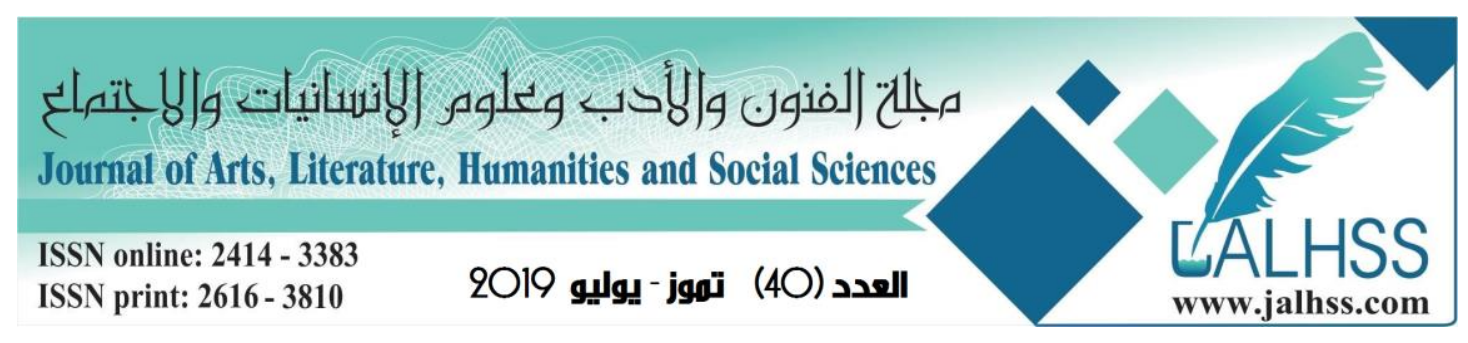

Eighth: The large volume of agricultural products:

This makes it more complicated that the volumes of most types of agricultural products are large and at disproportionate value, although the value is affected by multiple factors, and this large size requires:

1. Large stores.

2. Transport media of large or large volumes in transport modes

Ninth: The magnitude of the value of marketing services:

The small size of the agricultural units, the large number of agricultural units, the frequent production season and the large volume of agricultural products, which are mostly corrosive and contribute to increasing the need for marketing services and the value of their value, such as good and appropriate storage, fast transport and effective contribution in transporting products quickly from the field to warehouses and the need to flow properly according to the need of the requirements in terms of quantities, times and prices suitable for sale

\section{Cost Lists and Reports}

Cost lists can be defined as summary reports that include cost elements classified and arranged in a manner that serves certain purposes or uses. Lists are prepared for Costs based on multiple principles are related to the consideration of cost components and therefore we find that Cost lists are prepared on the basis of the theory of total, direct or exploited costs Variable. Here are some examples of cost lists in agricultural establishments according to the different loading considerations (Othman et al. 2015; Bockstael et 2000).

Table 1 List of crop production in accordance with the theory of the total costs

\begin{tabular}{|l|l|l|l|l|}
\hline \multirow{2}{*}{ The statement } & Crops & & \multirow{2}{*}{ Total } \\
\cline { 2 - 4 } & P1 & P2 & P3 & \\
\hline First: Direct agricultural costs & & & & \\
\hline A- Direct materials & $*$ & $*$ & $*$ & $* * *$ \\
\hline $\begin{array}{l}\text { B- Direct wages } \\
\text { Direct }\end{array}$ & $*$ & $*$ & $*$ & $* * *$ \\
\hline C- expenses & $*$ & $*$ & $*$ & $* * *$ \\
\hline Total direct costs & $* * *$ & $* * *$ & $* * *$ & $* * *$ \\
\hline Second: Indirect agricultural costs include fixed & & & & \\
\hline A- indirect materials & $*$ & $*$ & $*$ & $* * *$ \\
\hline B- Indirect wages include fixed & $*$ & $*$ & $*$ & $* * *$ \\
\hline C- Indirect expenses include fixed & $*$ & $*$ & $*$ & $* * *$ \\
\hline $\begin{array}{l}\text { Third: The total cost of the crop represents the } \\
\text { cost of conversion of crops according to this } \\
\text { theory }\end{array}$ & $* * *$ & $* * *$ & $* * *$ & $* * *$ \\
\hline
\end{tabular}




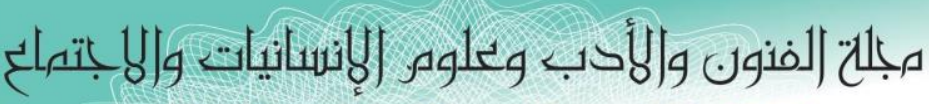

Journal of Arts, Literature, Humanities and Social Sciences

ISSN online: 2414 - 3383

ISSN print: $\mathbf{2 6 1 6}-\mathbf{3 8 1 0}$

\section{العدد (4O) تموز - يوليو 2019}

Table 2 Second: List of crop production according to the consideration of direct costs

\begin{tabular}{|l|l|l|l|l|}
\hline The statement & Crops & & & Total \\
\cline { 2 - 5 } & P1 & P2 & P3 & \\
\hline First: Direct agricultural costs & & & & \\
\hline A- Direct materials & $*$ & $*$ & $*$ & $* * *$ \\
\hline $\begin{array}{l}\text { B- Direct wages } \\
\text { Direct }\end{array}$ & $*$ & $*$ & $*$ & $* * *$ \\
\hline C- expenses & $*$ & $*$ & $*$ & $* * *$ \\
\hline $\begin{array}{l}\text { Total direct costs represent the cost of the } \\
\text { conversion of the theory of crops in accordance } \\
\text { with this }\end{array}$ & $* * *$ & $* * *$ & $* * *$ & $* * *$ \\
\hline
\end{tabular}

Table 3 Third: The list of costs according to the theory of crop variable costs

\begin{tabular}{|l|l|l|l|l|}
\hline The statement & Crops & & & \multirow{2}{*}{ Total } \\
\cline { 2 - 5 } & P1 & P2 & P3 & \\
\hline First: Direct agricultural costs variable & & & & \\
\hline A- Direct materials Only variable & $*$ & $*$ & $*$ & $* * *$ \\
\hline $\begin{array}{l}\text { B- Direct wages Only variable } \\
\text { Direct }\end{array}$ & $*$ & $*$ & $*$ & $* * *$ \\
\hline C- expenses Only variable & $*$ & $*$ & $*$ & $* * *$ \\
\hline Total direct costs Only variable & $* * *$ & $* * *$ & $* * *$ & $* * *$ \\
\hline $\begin{array}{l}\text { Second, indirect costs of agricultural: variable } \\
\text { only }\end{array}$ & & & & \\
\hline A- indirect materials & $*$ & $*$ & $*$ & $* * *$ \\
\hline B- Indirect wages include fixed & $*$ & $*$ & $*$ & $* * *$ \\
\hline C- Indirect expenses include fixed & $*$ & $*$ & $*$ & $* * *$ \\
\hline $\begin{array}{l}\text { Total non - fixed costs } \\
\text { Variable only }\end{array}$ & $* * *$ & $* * *$ & $* * *$ & $* * *$ \\
\hline $\begin{array}{l}\text { Third: Total direct and indirect direct costs } \\
\text { The cost of conversion of crops produced in } \\
\text { accordance with this is a consideration... }\end{array}$ & $* * *$ & $* * *$ & $* * *$ & $* * *$ \\
\hline
\end{tabular}




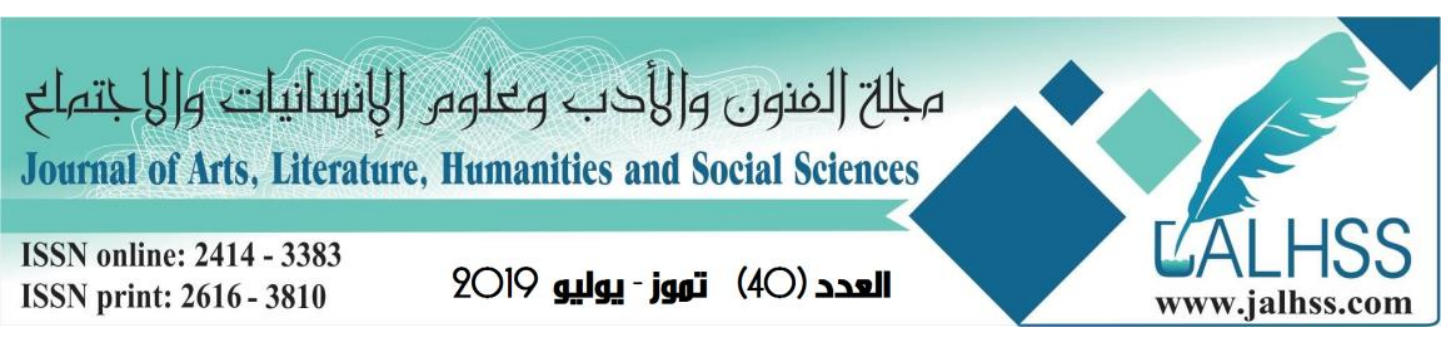

Table 4 Fourth: the list of the costs of crop production according to the theory of the exploited costs: 9

\begin{tabular}{|l|l|l|l|l|}
\hline The statement & Crops & & & \multirow{2}{*}{ Total } \\
\cline { 2 - 4 } & P1 & P2 & P3 & \\
\hline $\begin{array}{l}\text { First: Direct agricultural costs: } \\
\text { Changing }\end{array}$ & & & & \\
\hline Direct materials & $*$ & $*$ & $*$ & $* * *$ \\
\hline Direct wages & $*$ & $*$ & $*$ & $* * *$ \\
\hline Direct expenses & $*$ & $*$ & $*$ & $* * *$ \\
\hline Total direct costs & $* * *$ & $* * *$ & $* * *$ & $* * *$ \\
\hline $\begin{array}{l}\text { Second: Indirect agricultural costs: } \\
\text { Changing only }\end{array}$ & & & & \\
\hline Variable indirect materials only & $*$ & $*$ & $*$ & $* * *$ \\
\hline Indirect variable wages only & $*$ & $*$ & $*$ & $* * *$ \\
\hline Variable indirect expenses only & $*$ & $*$ & $*$ & $* * *$ \\
\hline Total non - fixed variable costs only & $* * *$ & $* * *$ & $* * *$ & $* * *$ \\
\hline $\begin{array}{l}\text { Third- Fixed indirect agricultural costs } \\
\text { Exploited: }\end{array}$ & $* * *$ & $* * *$ & $* * *$ & $* * *$ \\
\hline Fixed wages are exploited & $*$ & $*$ & $*$ & $* * *$ \\
\hline Fixed fixed expenses & $*$ & $*$ & $*$ & $* * *$ \\
\hline Total fixed fixed costs & $*$ & $*$ & $*$ & $* * *$ \\
\hline $\begin{array}{l}\text { Fourthly, the total costs that are exploited and } \\
\text { represent } \\
\begin{array}{l}\text { Cost of conversion of crops according to the } \\
\text { cost consideration Exploited }\end{array}\end{array}$ & $* * *$ & $* * *$ & $* * *$ & $* * *$ \\
\hline
\end{tabular}

Fifth: Download the allocation of indirect agricultural costs: One of the objectives of the cost system is to charge all costs related to a given activity on the units of this activity in order to extract the cost of the produced unit, so that there is no remaining in. The end is a balance of costs without charge, as long as costs are incurred for this purpose. The units produced are the final stabilizers to be fully borne, and on this basis there are no "unpaid receivables" and "no advance payments" in the cost accounting. All belongs to the activity carried out in the agricultural establishment during the period. In other words the agricultural activity units are directly responsible for them, and they are assumed to be equal in which the complete units and the existing plantations are units under production.

\section{Society and Study Sample}

The study population consists of the current farmers of Balak agricultural projects. The sample of the study was randomly selected from the study population. It reached 


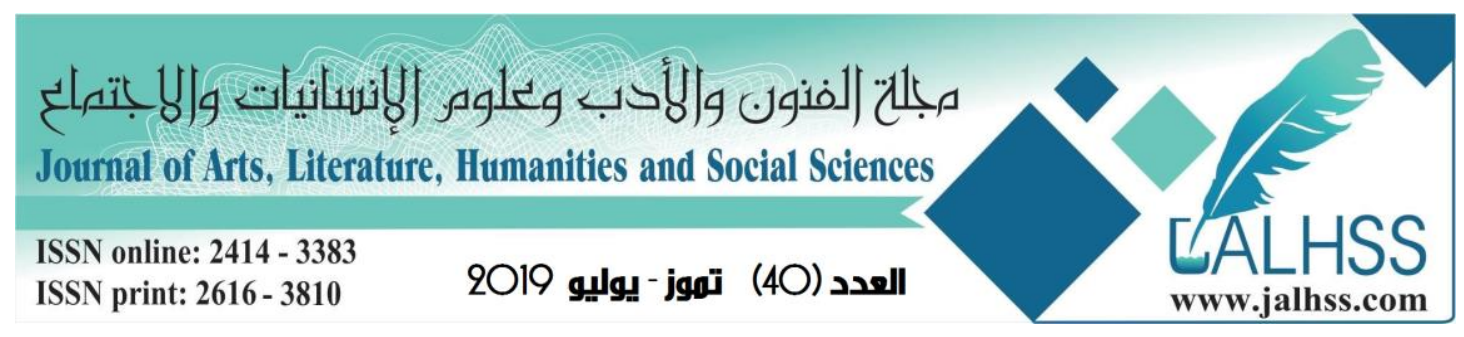

170 individuals, representing $10 \%$ of the study population. The 170 samples were distributed. The total number of non-retrieved responses was not fully filled. The questionnaire sample was 150 questionnaires, that is $89 \%$ of the number of distributed questionnaires, and this sample is relatively large in order to accept the results of the study and generalize it to the study community, and to produce results as accurate as possible to ensure the researcher to diversify the sample members of the study Respondents. This diversity in respondents' characteristics is related to their views on accounting Costs and their role in avoiding financial insolvency in Balak agricultural projects.

Level of education:

Table 5 Explain the relative distribution of respondents by iterative level of education

\begin{tabular}{|l|l|l|}
\hline Educational level & the number & the percentage \\
\hline Mom & 36 & 24.0 \\
\hline Free or basic & 79 & 53.0 \\
\hline Secondary & 29 & 19.0 \\
\hline Collectors & 6 & 4.0 \\
\hline Total & 150 & 100.0 \\
\hline
\end{tabular}

It is clear from the table and the figure above that the majority of respondents in the sample of the study level 79 percent, 53 percent and 36 percent of respondents are illiterate by $24 \%, 29 \%$ by $19 \%$, and $6 \%$ by the educational level and Collector by $4 \%$. Age:-

Table 6 Recurring relative distribution of respondents according to age variable

\begin{tabular}{|l|l|l|}
\hline Age & the number & the percentage $\%$ \\
\hline Less than 31 & 44 & 29 \\
\hline 31. To 45 years & 75 & 50 \\
\hline From 46 to 60 years & 31 & 21 \\
\hline total & 150 & 100 \\
\hline
\end{tabular}

It is clear from the table and the figure above that most of the respondents were aged in the range from (31 to 45$)$, where they reached $(75 \%),(50 \%)$ and $(44 \%)$ of the respondents $(29 \%)$ were under the age of 31 years, and $30 \%$ respondents were at their ages ranged from 36 to 60 percent ( 21 percent), and we note that age groups From 31 years to 45 , most of the respondents were sampled, and this is natural because they represent the summit of tender mixed with experience and knowledge. 


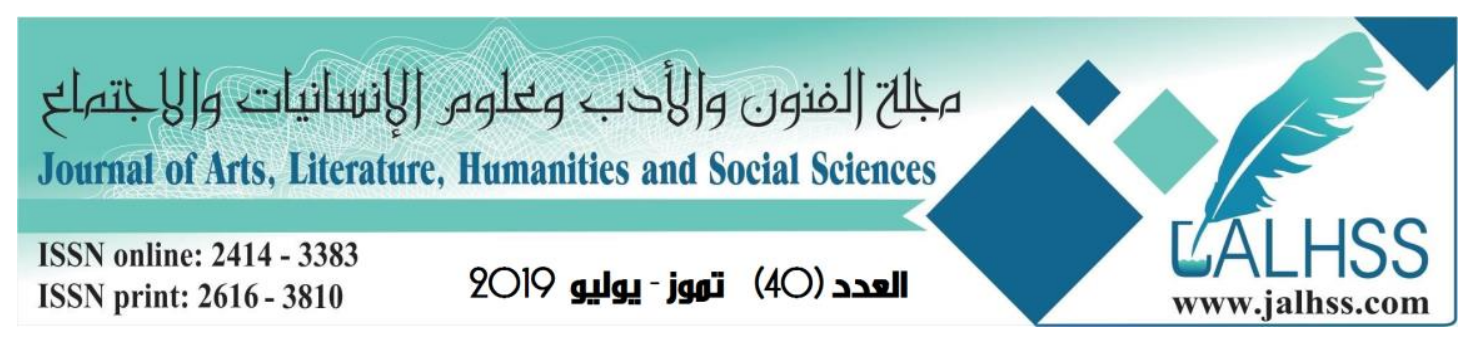

Years of Experience:-

Table 7 Relative frequency distribution of respondents by agricultural experience

\begin{tabular}{|l|l|l|}
\hline Experience & Number & Percentage $\%$ \\
\hline Less 6 y & 9 & 6 \\
\hline $6-10 \mathrm{y}$ & 47 & 31 \\
\hline $11-20$ & 64 & 43 \\
\hline $21-30$ & 27 & 18 \\
\hline $31-$ And more & 3 & 2 \\
\hline
\end{tabular}

It is clear from the table and the figure above that most of the respondents had experience in agriculture from (11 to 20 years), (43 percent) and 47 (their agricultural experience was in the range of 6) To (10\%), (31\%) and (27\%) of the respondents in the range of (21 to 30$)$ ), (18\%) and (3\% of respondents) (2\%) had 31 years of experience and more), indicating that these respondents have experience in this area and can benefit of their views.

\section{Test the hypotheses of the study}

Distribution is one of the most important statistical tools used in analysis of social phenomena, both descriptive and non-descriptive. So it is often not free studies and political research that follow the quantitative or behavioral method of application or use this method in statistical analysis. When data on the phenomenon under study are available in the form of duplicates (called Observation Frequencies), the comparison of these frequencies with what we expect is possible from reaching some of the characteristics of the society under study. Among the known applications for distribution are:

\section{Homogeneity test:}

Homogeneity or symmetry testing is an important application for the distribution of a square. The homogeneity test steps are as follows

1 No determination: is the imposition of homogeneity (or symmetry).

2. Alternative assumption: is heterogeneity.

3. Statistic: The statistic takes the following form:

$$
x 2=\sum_{1}^{k} \frac{(0-e) 2}{e}
$$

Which has a $\mathrm{K} 2$ distribution with free degrees $\mathrm{K}$ - I where $\mathrm{K}$ is the number of cells or categories Phrases ..., $\mathrm{O}$ denotes the observed frequencies, e denotes expected recurrences Comparison and Resolution: Where the statistical value (calculated from step 3) is compared With a tabular value at the mean level (0.05), if the calculated value Less than the table is the decision to accept the null hypothesis (ie accepting the imposition of homogeneity) Conversely, if the calculated value is greater than the scale, the decision is to reject the hypothesis Nudity and accept substitution. 


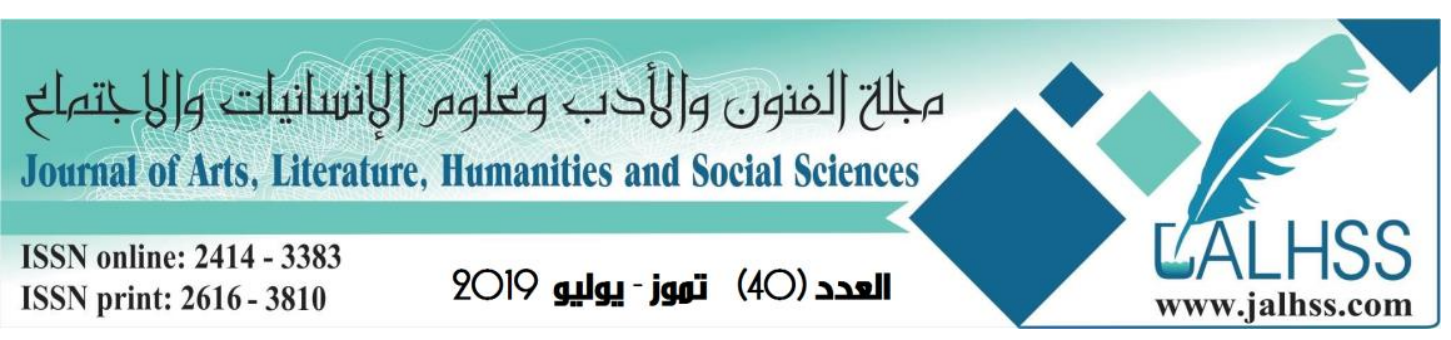

Acceptance of the imposition of heterogeneity at a level (Equal to 0.05) the researcher finds that this type of test is suitable for testing the hypotheses of the study.

\section{Initial hypothesis test:}

The initial hypothesis stated that the application of the agricultural cost accounting system helps To avoid agricultural insolvency) and to know the trends of respondents' opinions in the study sample To verify this hypothesis, the observed and expected frequencies of respondents' responses were calculated On each of the hypothesis statements, in order to find the value of the calculated ki square and the table 8 explains this projected and expected frequency and the results of a square box test for the initial hypothesis paragraphs.

Table 8 The projected and expected frequency

\begin{tabular}{|c|c|c|c|c|c|c|c|c|c|}
\hline Phrases & Repetition & $\begin{array}{l}\text { totally } \\
\text { agree }\end{array}$ & agree & $\begin{array}{l}\text { Not } \\
\text { sure }\end{array}$ & $\begin{array}{l}\text { I } \\
\text { don't } \\
\text { agree }\end{array}$ & $\begin{array}{l}\text { totally } \\
\text { not } \\
\text { agree }\end{array}$ & $\begin{array}{l}\text { Calculated } \\
\text { value }\end{array}$ & $\begin{array}{l}\text { Degree of } \\
\text { freedom }\end{array}$ & $\begin{array}{l}\text { Tabulated } \\
\text { value }\end{array}$ \\
\hline $\begin{array}{l}\text { There are } \\
\text { documents } \\
\text { (exchange } \\
\text { permissions, } \\
\text { Cards (supporting } \\
\text { and confirming } \\
\text { exchange } \\
\text { On-the-job funding }\end{array}$ & $\begin{array}{l}\text { The } \\
\text { scenes }\end{array}$ & 7 & 2 & 12 & 42 & 77 & 11.7 & 4 & 9.81 \\
\hline $\begin{array}{l}\text { Expenses are } \\
\text { recorded first-time } \\
\text { on } \\
\text { Specific books }\end{array}$ & $\begin{array}{l}\text { The } \\
\text { scenes }\end{array}$ & 3 & 14 & 12 & 47 & 74 & 11.7 & 4 & 9.81 \\
\hline $\begin{array}{l}\text { Regular accounting } \\
\text { books are available } \\
\text { Records and } \\
\text { transfers expenses } \\
\text { And revenues }\end{array}$ & $\begin{array}{l}\text { The } \\
\text { scenes }\end{array}$ & 7 & 7 & 15 & 45 & 76 & 12 & 4 & 9.81 \\
\hline $\begin{array}{l}\text { Reference is made } \\
\text { to books and } \\
\text { records } \\
\text { To determine the } \\
\text { repayment position } \\
\text { of loans }\end{array}$ & $\begin{array}{l}\text { The } \\
\text { scenes }\end{array}$ & 20 & 11 & 16 & 46 & 57 & 12 & 4 & 9.81 \\
\hline $\begin{array}{lr}\begin{array}{l}\text { Stage based } \\
\text { reports }\end{array} & \text { on } \\
\text { illustrate } & \text { that } \\
\text { Agriculture } & \\
\text { position } & \end{array}$ & $\begin{array}{l}\text { The } \\
\text { scenes }\end{array}$ & - & - & 13 & 60 & 77 & 54.7 & 2 & 9.81 \\
\hline $\begin{array}{l}\text { There is follow-up } \\
\text { to the disbursement }\end{array}$ & $\begin{array}{l}\text { The } \\
\text { scenes }\end{array}$ & 2 & 2 & 3 & 75 & 68 & 43.9 & 4 & 9.81 \\
\hline
\end{tabular}




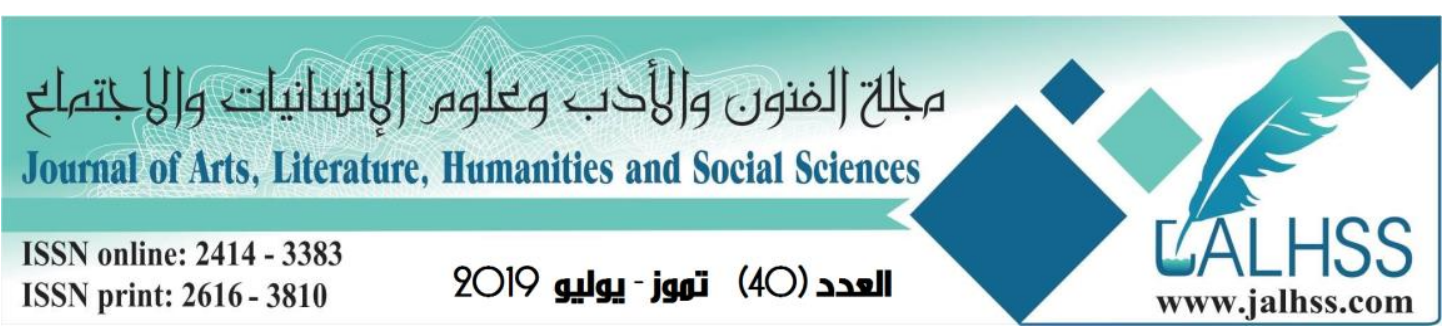

\begin{tabular}{|l|l|l|l|l|l|l|l|l|l|}
\hline $\begin{array}{l}\text { of loans } \\
\text { On agricultural } \\
\text { operations } \\
\text { As estimated }\end{array}$ & & & & & & & & & \\
\hline $\begin{array}{l}\text { There is agneral } \\
\text { ledger in which } \\
\text { every one is } \\
\text { assigned } \\
\text { Agricultural Cost } \\
\text { Data during } \\
\text { Period } \\
\text { sultivation of }\end{array}$ & 17 & 29 & 11 & 33 & 68 & 19.2 & 4 & 9.81 \\
\hline $\begin{array}{l}\text { The funding is } \\
\text { interviewed } \\
\text { according to each }\end{array}$ & $\begin{array}{l}\text { The } \\
\text { scenes }\end{array}$ & 30 & 30 & 30 & 30 & 30 & 11 & 4 & 9.81 \\
\hline $\begin{array}{l}\text { All agricultural } \\
\text { funding is } \\
\text { disbursed agricultural } \\
\text { On } \\
\text { operations of crops } \\
\begin{array}{l}\text { Which are } \\
\text { cultivated }\end{array}\end{array}$ & $\begin{array}{l}\text { The } \\
\text { scenes }\end{array}$ & 13 & 22 & 12 & 50 & 53 & 53.5 & 4 & 9.81 \\
\hline
\end{tabular}

From the previous table, show the following:

- The value of the square calculated to denote the differences between the responses of the different respondents

The first paragraph (11.7) is larger than the value of the square extracted from the $\mathrm{c}$. below the moral level (5\% and free degrees) (4), (9.81). There were significant differences between respondents' responses to this paragraph and those who did not. They agree that there are documents (exchange permits, purchase orders, cards) that support and confirm disbursement

On-the-job funding.

- The value of the square calculated to indicate the differences between the responses of the different respondents to the paragraph (11.7) This value is greater than the value of the square extracted from the table below the level $(5 \%)$, and $(9.81 \%)$, this result indicates differences

And the respondents who did not agree with it Expenses are recorded first-time in specific books.

- The value of the square calculated to indicate the differences between the responses of the different respondents to the paragraph (12) This value is greater than the value of the square extracted from the table below the level (5\%), and $(9.81 \%)$, this result indicates differences.

And the respondents who did not agree to provide regular accounting books to record and transfer expenses and revenues. 


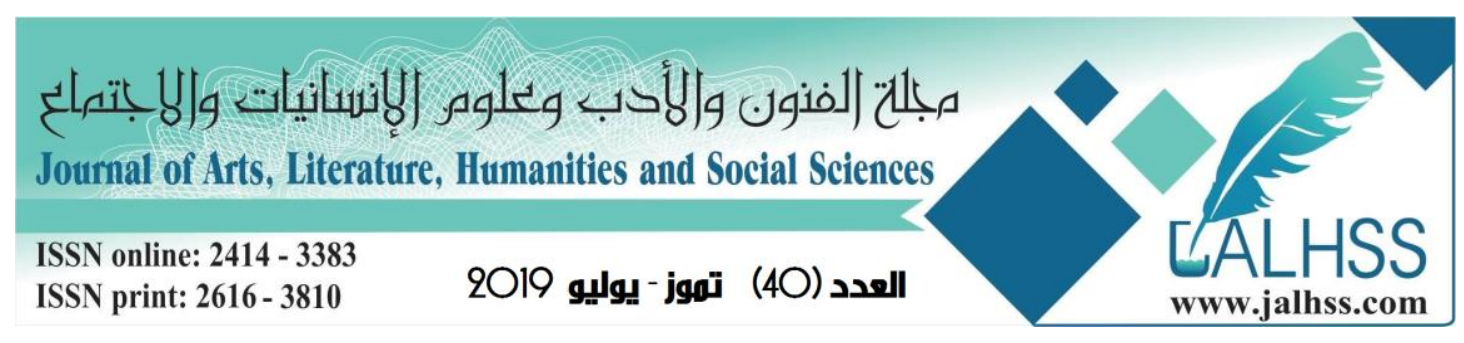

- The value of the square calculated to indicate the differences between the responses of the different respondents to the paragraph (54.7). This value is greater than the value of the square extracted from the table below the level (3\%) and (7.28\%). This result indicates that there are differences are done of the respondents' responses to this paragraph and to respondents who did not agree Interview the funding provided by each stage based on reports showing the position of agriculture. The value of the square calculated to denote the differences between the responses of the different respondents to the paragraph touch (43.9). This value is greater than the value of the square extracted from the table below (5\%) and free degrees (2 adults), 5.99 indicates that there is a significant difference. There were significant differences between respondents' responses to this paragraph and those who did not agree. However, there is a general ledger in which all data on agricultural costs are deposited during the period of cultivation.

- The value of the square calculated to denote the differences between the responses of the different respondents (Paragraph 19.2) This value is greater than the value of the square extracted from the table Below the moral level (5\% and free degrees) (4), (9.81) indicates this result There were significant differences between respondents' responses to this paragraph and to the respondents Who did not agree that funding should be met at each stage based on reports Explains the position of agriculture The value of the Kay square calculated to indicate differences between the responses of different respondents was (Paragraph 11). This value is greater than the value of the square extracted from the table below the moral level (5\% and free degrees) (3 adults), 9.81 indicates this result.

There were significant differences between respondents' responses to this paragraph and to the respondents who did not agree to follow-up on the disbursement of loans in kind to operations agriculture according to what is estimated. The value of the Kay square calculated to indicate differences between the responses of different respondents was (Para. 53.5). This value is greater than the value of the square extracted from the table below the moral level (5\% and free degrees) (4), (9.81) indicates this result. There were significant differences between respondents' responses to this paragraph and to the respondents who did not agree that all agricultural funding is spent on agricultural operations planted.

- The value of the square calculated to denote the differences between the responses of the different respondents (87.7). This value is greater than the value of the Kay box extracted from the table below the moral level) (5\% and free degrees) ( 3 adults), 7.28 indicates this result.

There were significant differences between respondents' responses to all these paragraphs

Respondents who agreed that the application of the Agricultural Cost Accounting System (CASA) help to avoid agricultural insolvency. 


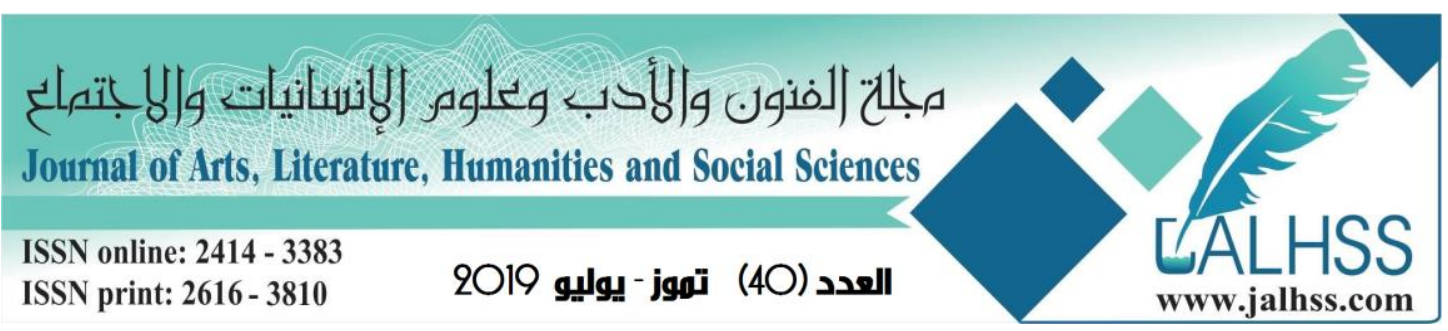

We conclude that the hypothesis of the preliminary study, which provided for the application of an accounting system (Agricultural costs help to avoid agricultural insolvency) have been achieved through the value of the square of Kai for all the phrases (87.7) is greater than the value of the square of Kai extracted from Table (7.28 at a significant level).

Test the second hypothesis:

The second hypothesis of the study hypotheses states: "There is a significant relationship (Between finance and means of avoiding agricultural insolvency) and to identify views. Respondents in the sample of the study to the extent to which this hypothesis has been achieved have been calculated predictively and expected responses of respondents to each hypothesis.

Table 9 The expected and expected recurrence of the results of the second square test of the second hypotheses.

\begin{tabular}{|c|c|c|c|c|c|c|c|c|c|}
\hline Phrases & Repetition & $\begin{array}{l}\text { totally } \\
\text { agree }\end{array}$ & agree & $\begin{array}{l}\text { Not } \\
\text { sure }\end{array}$ & $\begin{array}{l}\text { I } \\
\text { don't } \\
\text { agree }\end{array}$ & $\begin{array}{l}\text { totally } \\
\text { not } \\
\text { agree }\end{array}$ & $\begin{array}{l}\text { Calculated } \\
\text { value }\end{array}$ & $\begin{array}{l}\text { Degree } \\
\text { of } \\
\text { freedom }\end{array}$ & $\begin{array}{l}\text { Tabulated } \\
\text { value }\end{array}$ \\
\hline $\begin{array}{l}\text { There is a delay in } \\
\text { granting funding } \\
\text { Than Delays in the } \\
\text { timing of agricultural } \\
\text { operations }\end{array}$ & $\begin{array}{l}\text { The } \\
\text { scenes }\end{array}$ & 67 & 55 & 13 & 9 & 6 & 11 & 4 & 9.81 \\
\hline $\begin{array}{l}\text { MFIs focus on } \\
\text { Guarantees without a } \\
\text { priori consideration } \\
\text { To the feasibility of } \\
\text { agricultural activity }\end{array}$ & $\begin{array}{l}\text { The } \\
\text { scenes }\end{array}$ & 66 & 51 & 4 & 13 & 16 & 96.6 & 4 & 9.81 \\
\hline $\begin{array}{l}\text { Funding is limited to } \\
\text { eyes only } \\
\text { (A) for cash and } \\
\text { fertilizer (excluding } \\
\text { cash) } \\
\text { Disabled in the } \\
\text { remaining stages of } \\
\text { agriculture } \\
\text { Requires } \\
\text { exchange }\end{array}$ & $\begin{array}{l}\text { The } \\
\text { scenes }\end{array}$ & 89 & 48 & 4 & 8 & 1 & 19.3 & 4 & 9.81 \\
\hline $\begin{array}{l}\text { Most farmers do not } \\
\text { charge a cost } \\
\text { Funding to add to the } \\
\text { costs of the activity } \\
\text { Agricultural sector }\end{array}$ & $\begin{array}{l}\text { The } \\
\text { scenes }\end{array}$ & & & & & & & 4 & 9.81 \\
\hline $\begin{array}{l}\text { Funding repayment } \\
\text { dates coincide } \\
\text { With the time of }\end{array}$ & $\begin{array}{l}\text { The } \\
\text { scenes }\end{array}$ & & & & & & & 4 & 9.81 \\
\hline
\end{tabular}




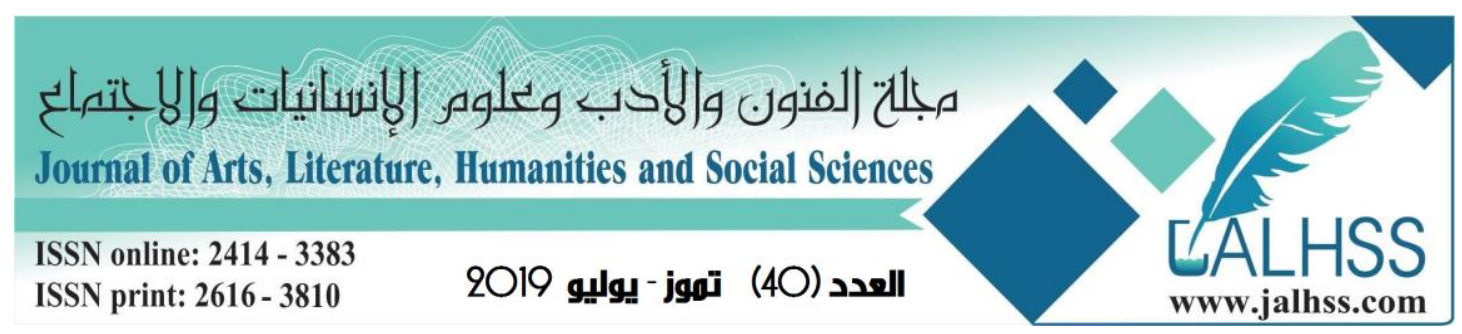

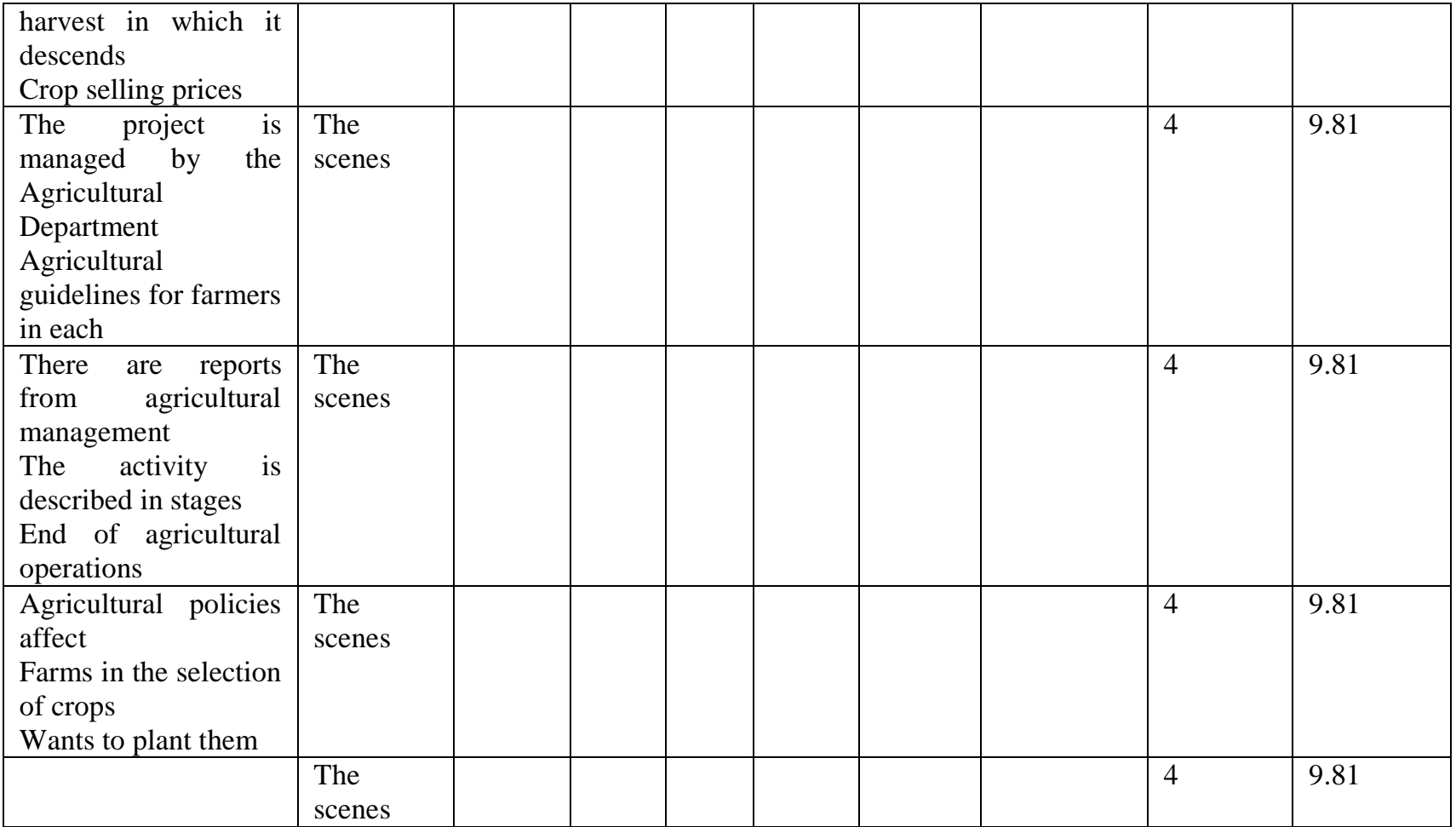

From the table above, the following are shown:

- The value of the square calculated to denote the differences between the responses of the different respondents The first paragraph (11) is larger than the value of the square extracted from the table Below the moral level (5\% and free degrees) (4), (9.81) indicates this result.

There were significant differences between respondents' responses to this paragraph and to the respondents who agreed that there was a delay in granting funding which delayed the timing of operations.

Agriculture.

- The value of the square calculated to denote the differences between the responses of the different respondents The second paragraph (96.6) is larger than the value of the square of Kai extracted from the table Below the moral level (5\% and free degrees) (4), (9.81) indicates this result. There were significant differences between respondents' responses to this paragraph and to the respondents who agreed that MFIs were primarily focusing on safeguards considering the feasibility of agricultural activity, which led to the use of some farmers to finance the other areas.

The value of the square calculated to indicate the differences between the responses of different respondents (3) (19.3). This value is greater than the value of the square extracted from the table 


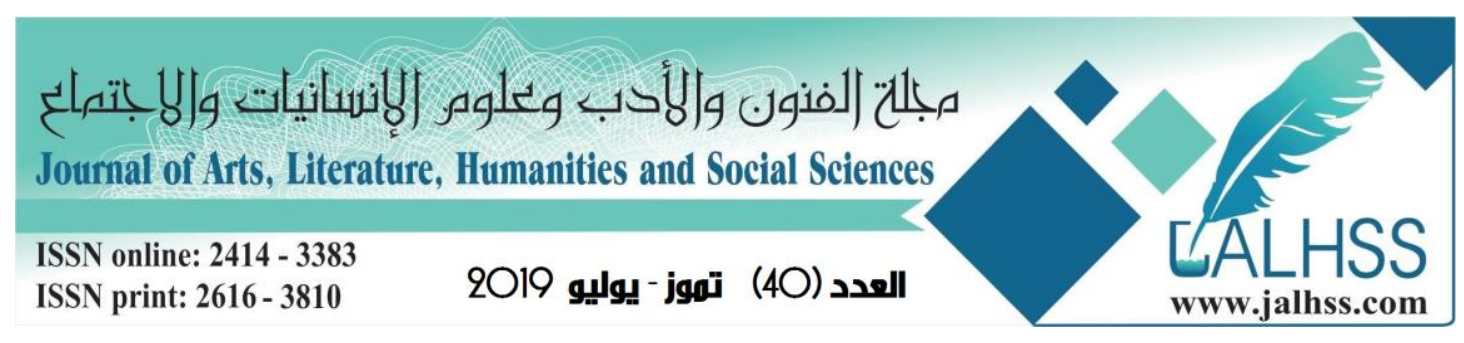

Below the moral level (5\% and free degrees) (4), (9.81) indicates this result. There were significant differences between respondents' responses to this paragraph and to the respondents who agreed that funding should be limited to the eyes only (for collection and fertilizer) without cash is a handicap in the remaining stages of agriculture that require cash disbursement.

- The value of the square calculated to denote the differences between the responses of the different respondents are good (See paragraph 50.6). This value is greater than the value of the square extracted from the table below the moral level (5\% and free degrees) (4), (9.81) indicates this result. There were significant differences between respondents' responses to this paragraph and to the respondents who agreed that most farmers did not calculate the cost of funding to add them to costs agricultural activity.

- The value of the square calculated to denote the differences between the responses of the different respondents Touch Para. (12.4). This value is greater than the value of the square extracted from the table below the moral level (5\% and free degrees) (4), (9.81) indicates this result. There were significant differences between respondents' responses to this paragraph and to the respondents who agreed that the repayment dates of the financing loans coincide with the harvest time. The prices of crop sales are low.

The value of the square calculated to indicate the differences between the responses of different respondents (86.3). This value is greater than the value of the square extracted from the table below the moral level (5\% and free degrees) (4), (9.81) indicates this result. There were significant differences between respondents' responses to this paragraph and to the respondents who did not agree that the Agricultural Department of the project would undertake agricultural guidance for farmers in all stages of agricultural operations.

- The value of the square calculated to denote the differences between the responses of the different respondents (54.4). This value is greater than the value of the square extracted from the table below the moral level (5\% and free degrees) (4), (9.81) indicates this result. There were significant differences between respondents' responses to this paragraph and to the respondents who did not agree that there were reports from the Agricultural Administration showing the progress of the activity and the stages of agricultural operations till the end of harvest.

The value of the square calculated to indicate the differences between the responses of different respondents. The previous paragraph (95) is larger than the value of the square extracted from the table. Below the moral level (5\% and free degrees) (4), (9.81) indicates this result. There were significant differences between respondents' responses to this paragraph and to the respondents who agreed that agricultural policies affect farmers' freedom of choice of crops that want to grow.

The value of the square calculated to denote the differences between the responses of the different respondents. All paragraphs (96.3) and this value are greater than the 


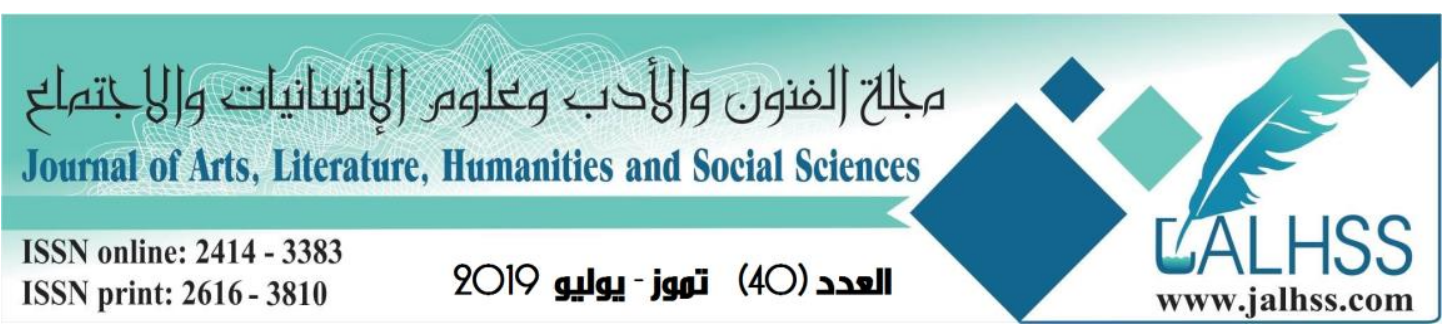

value of the Kay box extracted from the table. Below the moral level (5\% and free degrees) (4), (9.81) indicates this result. There were significant differences between respondents' responses to all these paragraphs. Of respondents who agreed that there was a statistically significant relationship between funding and ways to avoid agricultural insolvency.

From this we conclude that the hypothesis of the second study, which states: "There is a significant relationship (Statistically between finance and means of avoiding agricultural insolvency) have been achieved. The value of the square of Kai for all the phrases (87.7) is greater than the value of the square of Kai Extracted from Table 10 at a significant level.

Table 10 Avoiding Agricultural Insolvency

\begin{tabular}{|c|c|c|c|c|c|c|c|c|c|}
\hline Phrases & Repetition & $\begin{array}{l}\text { totally } \\
\text { agree }\end{array}$ & agree & $\begin{array}{l}\text { Not } \\
\text { sure }\end{array}$ & $\begin{array}{l}\text { I } \\
\text { don't } \\
\text { agree }\end{array}$ & $\begin{array}{l}\text { totally } \\
\text { not } \\
\text { agree }\end{array}$ & $\begin{array}{l}\text { Calculated } \\
\text { value }\end{array}$ & $\begin{array}{l}\text { Degree } \\
\text { of } \\
\text { freedom }\end{array}$ & $\begin{array}{l}\text { Tabulated } \\
\text { value }\end{array}$ \\
\hline $\begin{array}{l}\text { The amount of crops } \\
\text { to be selected is } \\
\text { determined } \\
\text { Production according } \\
\text { to the equivalent } \\
\text { Agriculture available }\end{array}$ & $\begin{array}{l}\text { The } \\
\text { scenes }\end{array}$ & 21 & 25 & 11 & 45 & 48 & 33.8 & 4 & 9.28 \\
\hline 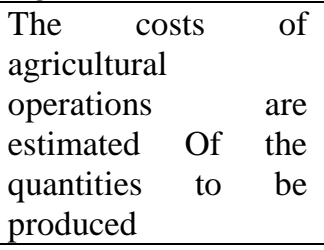 & $\begin{array}{l}\text { The } \\
\text { scenes }\end{array}$ & 53 & 50 & 12 & 22 & 13 & 53.5 & 4 & 9.28 \\
\hline $\begin{array}{l}\text { Production stages } \\
\text { Water cost and } \\
\text { prices are estimated } \\
\text { And the distribution } \\
\text { of the cost of stages } \\
\text { Agricultural } \\
\text { operations }\end{array}$ & $\begin{array}{l}\text { The } \\
\text { scenes }\end{array}$ & 27 & 23 & 6 & 50 & 44 & 41 & 4 & 9.28 \\
\hline $\begin{array}{l}\text { Estimated costs of } \\
\text { production elements } \\
\text { (Soil preparation, } \\
\text { manure and labor) } \\
\text { According to } \\
\text { agricultural stages } \\
30.7\end{array}$ & $\begin{array}{l}\text { The } \\
\text { scenes }\end{array}$ & 16 & 22 & 14 & 44 & 49 & 33 & 4 & 9.28 \\
\hline $\begin{array}{l}\text { Part of the funding is } \\
\text { allocated to pay } \\
\text { Transport, storage } \\
\text { and marketing costs }\end{array}$ & $\begin{array}{l}\text { The } \\
\text { scenes }\end{array}$ & 19 & 20 & 18 & 44 & 49 & 10.1 & 4 & 9.28 \\
\hline $\begin{array}{l}\text { The sale price is } \\
\text { determined by } \\
\text { Calculation of total }\end{array}$ & $\begin{array}{l}\text { The } \\
\text { scenes }\end{array}$ & 8 & 11 & 12 & 51 & 68 & 55.7 & 4 & 9.28 \\
\hline
\end{tabular}




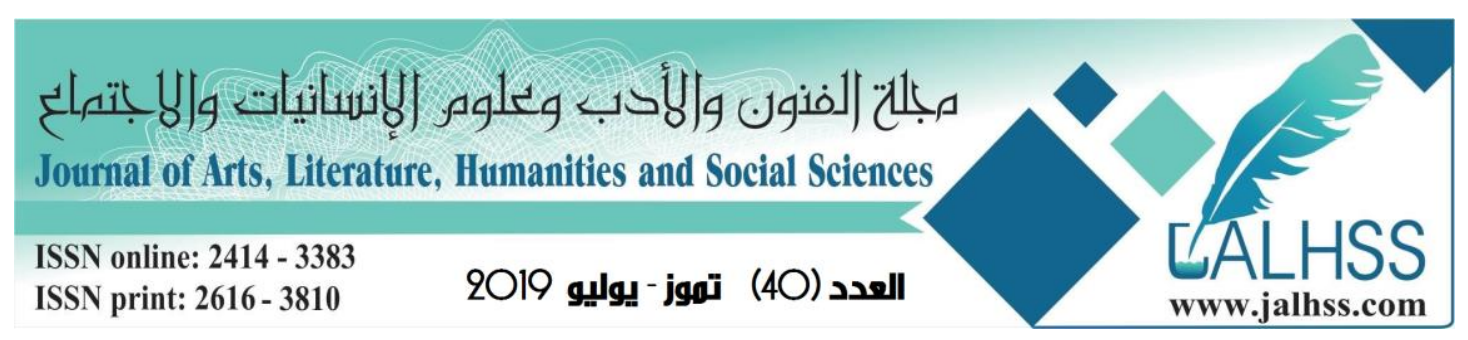

\begin{tabular}{|l|l|l|l|l|l|l|l|l|l|}
\hline $\begin{array}{l}\text { costs of production } \\
\text { Agricultural sector }\end{array}$ & & & & & & & & & \\
\hline $\begin{array}{l}\text { Estimated expenses } \\
\text { of the farmer and his } \\
\text { family } \\
\text { Of the funding } \\
\text { during the season } \\
\text { Agriculture }\end{array}$ & 12 & 23 & 13 & 43 & 59 & 48 & 4 & 9.28 \\
\hline $\begin{array}{l}\text { The cost of } \\
\text { agricultural land is } \\
\text { estimated at } \\
\text { Ownership, rent or } \\
\text { participation status }\end{array}$ & $\begin{array}{l}\text { The } \\
\text { scenes }\end{array}$ & - & - & 10 & 70 & 70 & 51.5 & 4 & 9.28 \\
\hline $\begin{array}{l}\text { An income account } \\
\text { is recognized when } \\
\text { selling and repay } \\
\text { Crop and } \\
\text { financing loans } \\
\text { For donors }\end{array}$ & $\begin{array}{l}\text { The } \\
\text { scenes }\end{array}$ & 12 & 23 & 13 & 52 & 50 & 68.9 & 4 & 9.28 \\
\hline $\begin{array}{l}\text { Cost lists and results } \\
\text { are prepared } \\
\text { Agricultural work } \\
\text { per year } \\
\text { For farmers by } \\
\text { accountants } \\
\text { Specialists }\end{array}$ & $\begin{array}{l}\text { The } \\
\text { scenes }\end{array}$ & 25 & 22 & 10 & 50 & 42 & 58.7 & 4 & 9.28 \\
\hline $\begin{array}{l}\text { Water fees are } \\
\text { appropriate and } \\
\text { payable annually }\end{array}$ & $\begin{array}{l}\text { The } \\
\text { scenes }\end{array}$ & - & - & 6 & 68 & 76 & 43.1 & 4 & \\
\hline
\end{tabular}

From the previous table shows the following:

- The value of the square calculated to denote the differences between the responses of the different respondents (33.8). This value is greater than the value of the square extracted from the table. Below the moral level (5\% and free degrees) (4), (9.81) indicates this result. There were significant differences between respondents' responses to this paragraph and to the respondents who did not agree that funding should be requested by the amount of targeted crops.

- The value of the square calculated to denote the differences between the responses of the different respondents of second paragraph (53.5). This value is greater than the value of the square Kay extracted from the table. Below the moral level (5\% and free degrees) (4), (9.81) indicates this result. There were significant differences between respondents' responses to this paragraph and to the respondents who did not agree that the amount of crops to be produced should be determined by Agricultural area available, owned or leased.

- The value of the square calculated to denote the differences between the responses of the different respondents. The third paragraph (41) is larger than the 


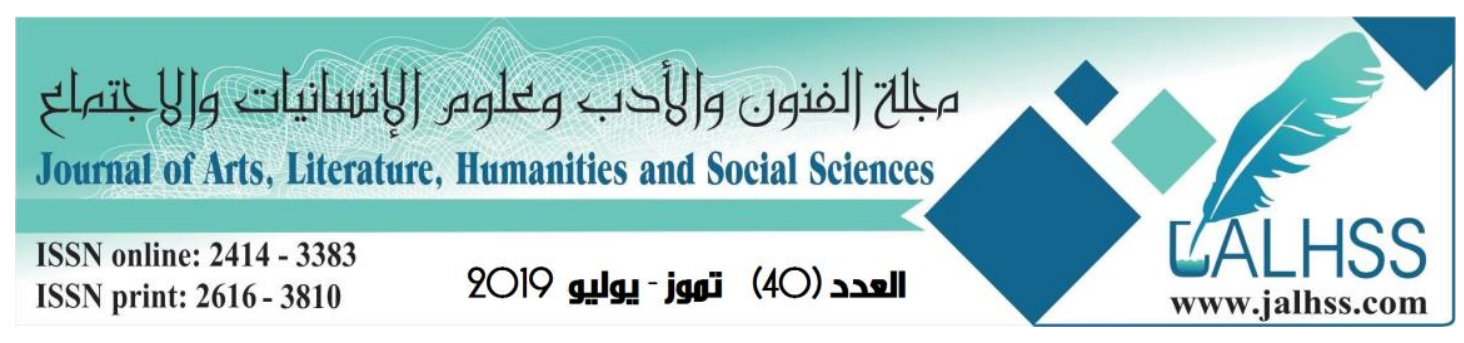

value of the square extracted from the table. Below the moral level $(5 \%$ and free degrees) (4), (9.81) indicates this result. There were significant differences between respondents' responses to this paragraph and to the respondents who did not agree that it estimated the costs of agricultural operations for the quantities to be produced depending on the production stages.

- The value of the square calculated to denote the differences between the responses of the different respondents is good in (Para. 33). This value is greater than the value of the square extracted from the table. Below the moral level (5\% and free degrees) (4), (9.81) indicates this result. There were significant differences between respondents' responses to this paragraph and to the respondents who did not agree that the cost and price of water is estimated and distributed at a phased cost Agricultural operations.

- The value of the square calculated to denote the differences between the responses of the different respondents touch Para. (30.7). This value is greater than the value of the square extracted from the table Below the moral level (5\% and free degrees) (4), (9.81) indicates this result There were significant differences between respondents' responses to this paragraph and to the respondents who did not agree that the costs of production (preparation and fertilizer) were estimated and employment (by agricultural stages).

- The value of the square calculated to denote the differences between the responses of the different respondents (6) (10.1). This value is greater than the value of the square extracted from the table. Below the moral level (5\% and free degrees) (4), (9.81) indicates this result. There were significant differences between respondents' responses to this paragraph and to the respondents who did not agree to earmark part of the funding to pay transportation and storage costs and marketing.

- The value of the square calculated to denote the differences between the responses of the different respondents in the previous paragraph (55.7) is larger than the value of the square extracted from the table below the moral level $(5 \%$ and free degrees) (4), (9.81) indicates this result. There were significant differences between respondents' responses to this paragraph and to the respondents who did not agree that the selling price was determined based on the total cost calculation for agricultural production.

- The value of the square calculated to denote the differences between the responses of the different respondents (8) (48). This value is greater than the value of the square extracted from the table below the moral level (5\% and free degrees) (2 adults), 5.99 indicates this result. There were significant differences between respondents' responses to this paragraph and to the respondents who did not agree that it estimated the expenses of the farmer and his family within the funding during Agricultural season.

- The value of the square calculated to denote the differences between the responses of the different respondents' capacity (Para. 51.5). This value is greater 


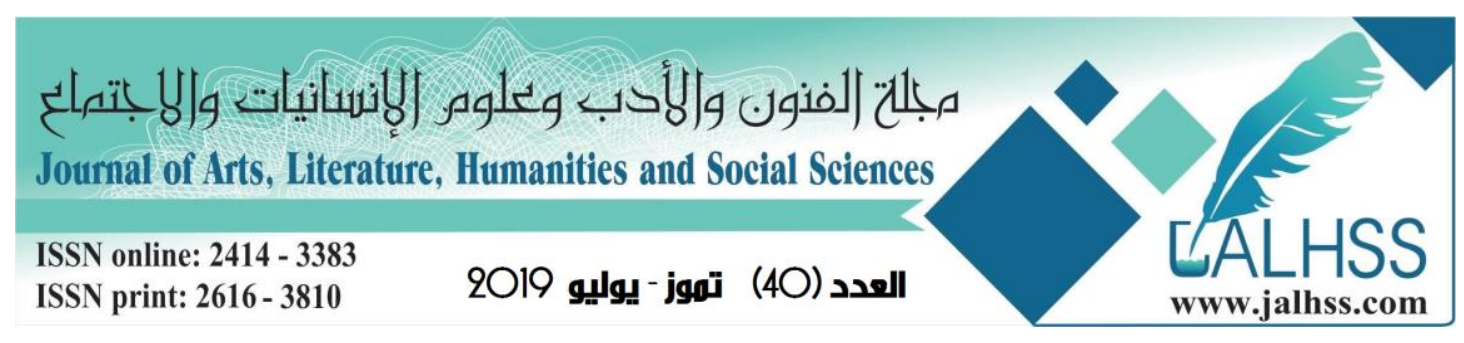

than the value of the square extracted from the table below the moral level (5\% and free degrees) (4), (9.81) indicates this result. There were significant differences between respondents' responses to this paragraph and to the respondents who did not agree that the cost of agricultural land was estimated in the case of ownership Rent or participation.

The value of a given square is used to denote differences between the responses of different respondents (X) (68.9). This value is greater than the value of the Kay box extracted from the table below the moral level (5\% and free degrees) (4), (9.81) indicates this result. There were significant differences between respondents' responses to this paragraph and to the respondents who did not agree that the calculation of farm income is made when the crop is sold and paid Grant when Financing loans to entities.

- The value of the square calculated to denote the differences between the responses of the different respondents Eleventh paragraph (58.7). This value is greater than the value of the square Kay extracted from The table below the moral level $(5 \%$ and free degrees) (2), 5.99 indicates this The results indicate that there are significant differences between the respondents' Respondents who did not agree that cost lists and agricultural results are prepared Annually to farmers through specialized accountants.

- The value of the square calculated to denote the differences between the responses of the different respondents (Para. (43.1)). This value is greater than the value of the square extracted from The table below the moral level $(5 \%)$ and free degrees (4), (9.81) indicates this The results indicate that there are significant differences between the respondents' Respondents who agreed that water fees should be considered appropriate and paid.

- The value of the square calculated to denote the differences between the responses of the different respondents All paragraphs (66.35) and this value are greater than the value of the square Kay extracted from the table is below the moral level $(5 \%$ and $5 \%)$. The result was that there were significant differences between respondents' responses to all these paragraphs. And for those respondents who agreed that the application of cost accounting would lead to achieving agricultural activity objectives. From this we conclude that the hypothesis of the third study, which states: "The application of accounting Estimated costs lead to achievement of the objectives of agricultural activity have been achieved through the value of the Kay box for all ferries is 66.35, which is larger than the value of the square (Extracted from Table 7.28) at a significant level of (\%5). 


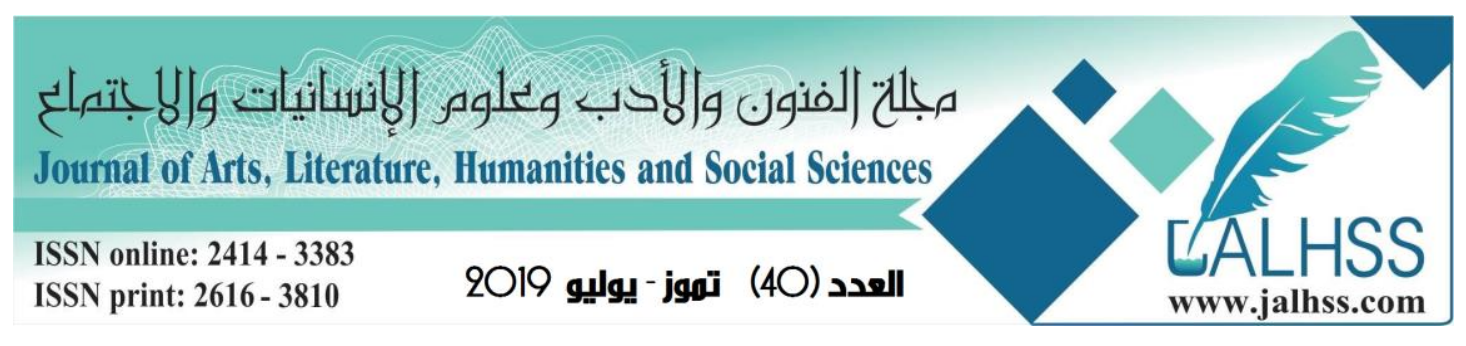

\section{Conclusion}

Through the study of the researcher to account for agricultural costs, financing and the causes of insolvency, I conclude, which includes the findings and recommendations.

Closing the estimate of the costs of production input and farm expenses, with no cost estimate agricultural land does not help to determine the size of costs and the real profit of a potential determining the selling price of the crop. There is a lack of agricultural extension from agricultural farm management and not to submit agricultural reports to the stages of agricultural operations and the position of agriculture to the parties funded and jurisdictions. No type of reports and lists showing the results of annual agricultural work are prepared. Failure to estimate funding for harvesting, transportation and storage costs affects the process of Economic marketing of crops.

\section{Recommendations:}

The researcher suggests the following recommendations:

The need for the application of the accounting of agricultural costs in agricultural projects for possible identification, there should be a trend towards a computerization program for cost reports on agricultural projects. The importance of establishing cost units in all agricultural projects, trying to train farmers on the basis of financial management with agricultural extension of their projects, it is recommended to create models of farmers' first books in which their expenses are recorded in a periodic manner.

\section{Reference}

1. Abdullah NN, Mohd, F (2015) Chinese Economic Activities and Interests in Developing Countries. Australian Journal of Basic and Applied Sciences 9(25): 79-86.

2. Hassan Abd ATi (2007), Technological change Agriculture Economic Trans for ma on in Northern Sudan.

3. John P. Hoehn and Alan Randall (1989), Too Many Proposals Pass the Benefit Cost Test, The American Economic Review, Vol. 79, No. 3, p. 544551.

4. Murices Moon (1999). The Basic Postulate of A counng research study No (1) 'New York American INSTI Tute certified public accountanls .,

5. Nambirajan T, Prabhu M. (2011) Competitiveness of Manufacturing Industries in Union Territory of Puducherry (India): A Critical Analysis. International Journal of Business Economics \& Management Research 2 (5): 54-65. 


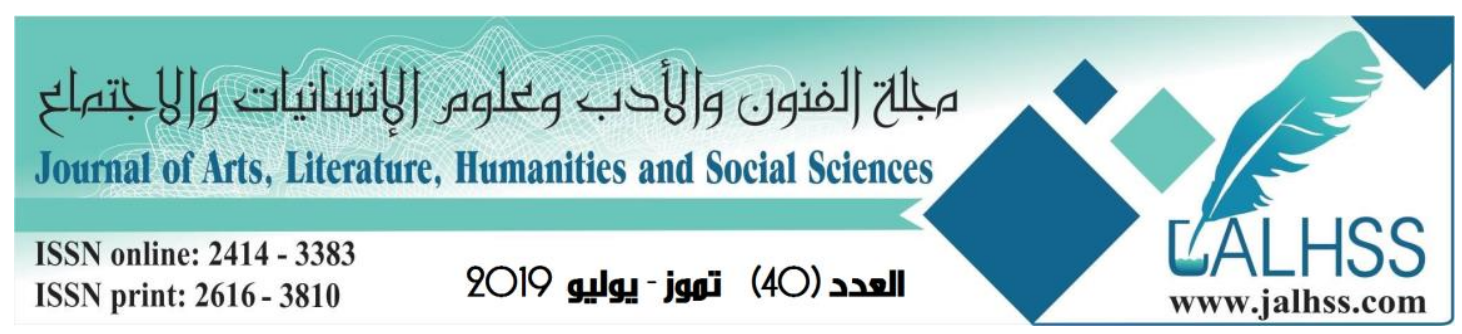

6. Nancy E. Bockstael, A. Myron Freeman III, Raymond J. Kopp, Paul R. Portney, and V Kerry Smith (2000), On Measuring Economic Values for Nature, Environmental Science \& TechnologyVol 34, No. 8, pp1384-1389.

7. Othman M, Saud MB, Mat Isa MA, Abdullah NN (2015) The Conceptual Assessment of Malaysian Entrepreneurship Environment and EO Economic Contribution. Journal of Resources Development and Management 20: 1520.

8. Grady P (2005). Inventory of generally prince bles for Business Eter prises, New York, AICP.

9. Prabhu M, Madan Mohan G (2014) A study on stress among university students in India. International Journal of Business and Administration Research Review 1(5): 21-33.

10. Rabiyathul Basariya S, Ramyar Rzgar Ahmed (2018) A Study on Consumer Satisfaction and Preference of Color TV Brands in Chennai City. International Research Journal of Management and Commerce 5(11): 47-60.

11. Rabiyathul Basariya S, Ramyar Rzgar Ahmed (2019) The Influence of Adventure Tourism Activities' in promoting tourism business in mountain stations. African Journal of Hospitality, Tourism and Leisure 8 (2): 1-10.

12. Richard B Norgaard, and Paul Baer (2003), Collectively Seeing Complex Systems: How we unite Understanding Across the Sciences.

13. Roseta-Palma, C. (2003). Joint quantity/quality management of groundwater. Environmental Resource Economics 26: 89-106.

14. Schuyt, K. and L. Brander (2004). Living waters: the economic value of the world's wetlands. WWF Gland/Amsterdam. Prepared with support from the Swiss Agency for the Environment, Forests, and Landscapes. January. 